American Journal of Pharmaceutical Education 2017; 81 (10) Article 6100.

\title{
RESEARCH
}

\section{Design and Implementation of an Elective on the Ethnopharmacology of Appalachia for the PharmD Curriculum}

\author{
Rebecca S. Linger, PhD \\ University of Charleston School of Pharmacy, Charleston, West Virginia \\ Submitted October 5, 2016; accepted March 14, 2017; published December 2017.
}

Objective. To create and implement a class in ethnopharmacology that would educate student pharmacists on folk medicine, including home remedies and native plants that are used as alternative medicinal sources; active components of medicinal plants including toxicity issues and the mechanism of action of beneficial compounds, such as catechins and other flavonoids; and nutraceuticals and poisonous plants.

Methods. In this three-credit hour class, herbal remedies are investigated from the standpoints of medical efficacy, potential toxicities and drug interactions with prescribed medications. Class discussions are conducted on the usefulness of remedies, the attitudes of practitioners toward traditional remedy use and the risks of relying on herbal preparations. Each student prepares a 15-minute presentation on a disease state, which covers modern pharmaceuticals and herbal or folk remedy alternatives used in that disease. Special emphasis is given to drug-herb interactions.

Results. The class has gained popularity among students and consistently fills within the first hour of computerized registration. Students agree that being educated in the benefits and potential toxicities of herbal products will better prepare them to counsel their patients who use these remedies. The elective has been offered 10 times since 2007. Anecdotal comments from our alumni indicate that they have found the information to be very useful in their practice environments.

Conclusion. Providing our students with a greater understanding of herbal remedies is essential to prepare them for practice. By including both the uses and potential toxicities, the student pharmacist is able to counsel her patients from a standpoint of expertise on these self-administered remedies.

Keywords: ethnopharmacology, Appalachia, alternative medicine, home remedies, folk medicine

\section{INTRODUCTION}

The popularity of herbal medicine and alternative remedies remains strong within the United States. The National Center for Health Statistics has conducted the National Health Interview Survey (NHIS) on complementary and alternative medicines nationwide since 1997. This survey, conducted every five years, asks adults living in the United States about their use of herbal preparations and dietary supplements. In 2012, the NHIS reported that 53.6 million Americans utilized herbal remedies and dietary supplements. ${ }^{1}$ The sale of botanical dietary supplements was estimated at $\$ 11.5$ billion in 2012. ${ }^{2}$ A population-based survey of 2,982 respondents conducted by Emory University in 2004 indicated that while $20 \%$ of the population used medicinal herbs, over $33 \%$ admitted to daily use. ${ }^{3}$ People who use dietary

Corresponding Author: Rebecca S. Linger, University of Charleston School of Pharmacy, 2300 MacCorkle Ave. SE, Charleston, WV 25304. Tel: 304-357-4998. Fax: 304-3574868. E-mail: rebeccalinger@ucwv.edu supplements report feeling an increase in general wellbeing and energy and feel that the supplements will help them fight or prevent various diseases. ${ }^{4}$ As our nation continues its pursuit of healthier lifestyles, we can expect the use of herbal supplements to continue to rise. Thus, the education of our student pharmacists in the uses of herbal supplements is of utmost importance.

In a 1998 report on complementary and alternative medicine (CAM) education in U.S. pharmacy schools, Rowell and Kroll indicated that $60 \%$ of schools responding presented herbal medicine in their curriculum, either in standalone classes or as part of the core curriculum. ${ }^{5}$ The guidelines they developed for CAM coursework for pharmacy schools stress the critical evaluation of the efficacy of the herbal remedies discussed. In 2003, Shields and colleagues found that $63 \%$ of schools responding had a specific course in natural products within their curriculum, with the majority of these classes offered as electives. ${ }^{6}$ In 2013, Noureldin and colleagues reported that while the majority of students surveyed had a positive 


\section{American Journal of Pharmaceutical Education 2017; 81 (10) Article 6100.}

opinion of CAM, students who had "personal experience, pharmacy education and family background" with CAM had a more favorable attitude toward its use. ${ }^{7}$

The importance of educating student pharmacists in the use and risks of herbal remedies cannot be overstated. The study of commercially available herbal supplements and an understanding of the lax regulatory oversight in their production are essential. The Dietary Supplement Health and Education Act of 1994 was established to help regulate products to be used for nutritional supplementation, but does not require certification or registration of active ingredients or potencies. ${ }^{8}$ Consequently, some commercially available nutritional supplements may contain insufficient quantities of active ingredients for efficacy, or competing brands may have significantly different concentrations of active ingredient leading to overdose or significant drug-herb interactions in the patient who is unaware that the concentration has increased from one brand to the next.

Given the large market for herbal supplements, it is interesting to note that many of the herbal remedies used today in Appalachia utilize foraged plants. The remedies have been passed down through oral tradition from ancestors who settled this area in the late 18th and early 19th century. For the uninitiated, descriptions of these remedies can be found in publications, such as almanacs, family medicine books and herbal texts, many of which date back to the homesteading period. Self-treatment with "tried and true" family remedies is part of the Appalachian spirit of self-reliance, which also includes the reluctance to seek outside medical attention. ${ }^{9}$ Although many Appalachians will admit to a lack of medical knowledge, their faith in family remedies will foment their reliance on self-treatment. Economic issues also influence their choices; many families do not have adequate health insurance, or medical personnel and facilities may be too far away. ${ }^{10}$ Pharmacy education in these rural areas should take these factors into account and include discussions of alternative remedies and practices of the local population.

According to Standard 12 of the "Accreditation Standards and Guidelines for the Professional Program in Pharmacy Leading to the Doctor of Pharmacy Degree" (Accreditation Council for Pharmacy Education 2016), ${ }^{11}$ "the didactic portion of the pre-APPE curriculum includes rigorous instruction in all sciences that define the profession" including "evidence-based evaluation of the therapeutic value, safety, and regulation of pharmacologically active natural products and dietary supplements. Cultural practices commonly selected by practitioners and/or patients for use in the promotion of health and wellness, and their potential impact on pharmacotherapy"
(Appendix 1 of Standards 2016). Patient-centered care must consider the health-literacy of the patient as well as any cultural issues that might need to be addressed. Student pharmacists need to understand the cultural background of their patients and be able to describe prescribed therapies and potential interactions in terms that can be understood by the patient. In this course, we expose the students to the folk lexicon of Appalachian residents, such as "risings" for hives or boils, "piles" for hemorrhoids, dropsy for edema. ${ }^{12}$ This sensitivity to the patient is also prescribed by the Center for the Advancement of Pharmaceutical Education (CAPE) 2013 Educational Outcomes, which describes within Domain 3 the need to advocate for the patients' best interests in a way that engages cultural sensitivity. ${ }^{13}$

This article describes the design and implementation of a class in ethnopharmacology. The University of Charleston resides in the heart of Appalachia. Approximately $70 \%$ of the students come from counties considered part of Appalachia by the Appalachian Regional Commission. Focusing on herbal supplement and folk medicine use following the traditions of Appalachia, this class adequately trains students to counsel their patients in a more culturally sensitive manner.

\section{METHODS}

Ethnopharmacology of Appalachia (PHAR 531) is a three-credit hour elective offered in the first professional year. The entire class is taught by one professor and enrollment is kept to a maximum of 20 students to facilitate in-class discussion. The primary focus of the class is to introduce students to the practice of herbal and home remedies. The review of student assessments and the evaluation of the course was submitted as a research project to the University of Charleston Institutional Review Board and found to be exempt.

Many students are interested in studying folk medicine because their families have traditionally used these types of remedies, and the student is curious to learn the efficacy of these treatments. The class seeks to present various medicinal plants focusing on the relative potencies of these remedies and the potential toxicities of use. Class material is presented in a variety of formats. Videos by the Appalachian naturalist, Ila Hatter, are presented where she discusses the uses of local medicinal and edible plants. ${ }^{14}$ Didactic lectures of medicinal herbs are given with PowerPoint slides supporting the discussion. Laboratory days are included in the curriculum, where students are exposed to the methods of herbal remedy preparation through hands-on experience. Two "herbal" products are compounded: a hand cream consisting of beeswax, 


\section{American Journal of Pharmaceutical Education 2017; 81 (10) Article 6100.}

almond oil and vitamin E, and an insect repellent of tea tree oil, lavender oil and witch hazel. The use of infusions is investigated with a day of brewing and discussion of the medicinal properties of various herbal teas. Finally, each student prepares an oral presentation on a disease state and the herbal remedies used to treat that disease and writes a term paper on a specific herbal remedy.

The class begins with discussions of the nature of folk medicine and its roots in the history of medicine (Table 1). This lecture includes discussion of ancient Western texts on medicinal plants (eg. Disocorides' Materia Medica) ${ }^{15}$ as well as Eastern references (eg, The Yellow Emperor's Classic of Medicine). ${ }^{16}$ Appalachian folk medicine is derived from the European ethnopharmacological tradition mixing with the knowledge of the indigenous peoples of the Americas. European settlers to Appalachia brought with them useful European plants but also learned of the medicinal properties of local plants from the Native American tribes of Appalachia. An example of cross-cultural sharing is seen with the European plant, mullein. It was used by the Europeans as an expectorant for pulmonary issues, which the Native Americans adopted, but also found that the thick leaves made a good insole cushion for their moccasins. The "Doctrine of Signatures" is discussed to explain why some plants have been associated with certain illnesses; specifically, the shape of the plant or where it grows gives clues to how the plant is to be used. In all these discussions, a heavy dose of skepticism is introduced and supported by scientific evidence that sometimes refutes, sometimes supports the validity of herbal remedies. The idea that many herbal remedies are effective and can cause severe side effects for patients on chronic therapy is emphasized. A great deal of time is devoted to herb/drug interactions and is the focus of the first in-class presentation. Each student will report on an herbal remedy and discuss the potential toxicities and drug interactions with that herbal. A class discussion on herbalists and faith healers allows students to describe their experiences with these practitioners. These discussions allow the students to learn compassion for others who may not hold the same beliefs that they have regarding folk medicine and faith healing. Students are encouraged to share their own experiences with the discussed remedies during lecture. A class session is devoted to students describing the home remedies used by their family. To facilitate this discussion, the class was given an assignment prior to the first day of class to ask their families about any home remedies they are using or may have used in the past. Our student body comes from a diverse set of backgrounds and each student's contribution is often unique.

Finally, each student is expected to research a disease state and prepare a Microsoft PowerPoint (Redmond, WA) presentation of 10-15 minutes in length on the following topics: discussion of disease state, herbals used to treat the disease, preparation and active compounds in the herbals used, mechanism of action of these active compounds in the treatment of the disease presented, herbdrug interactions or other toxicities associated with the use of the herbal, and the presentation of any official medications derived from these herbals. A rubric is used to assess the student's ability to present (Appendix 1). Areas assessed cover the nonverbal skills of eye contact, body language and poise, verbal skills of enthusiasm and elocution, content issues such as subject knowledge, organization and mechanics of giving a presentation, spelling and grammar. The creation of PowerPoint slides is assessed, evaluating the readability of the slide set and how the student uses the slides in the presentation. Students who create visually interesting slides that are easily read with bullet points that prompt their discussion are graded very highly in this section of the assessment.

Students were assigned to write a five-page essay on a particular herbal remedy, answering the following

Table 1. Lecture Topics

Introduction to Ethnopharmacology (1 hr)

Herbal Preparations (3 hrs)

Abandoned Theories of Illness ( $2 \mathrm{hrs}$ )

Alternative Medicine (2 hrs)

Our Family Remedies (2 hrs)

Poisonous Plants (2 hrs)

Some Commonly Used Herbal Remedies (4 hrs)

Patent Medicines (1 hr)

Flavonoids and Nutraceuticals (1hr)

Herb-Drug Interactions (2 hrs)

Ethnobotanical Uses of Appalachian Plants ( $2 \mathrm{hrs}$ )

Compounding Lab: Beeswax/Almond Oil Hand Cream, Tea Tree Oil, Witch Hazel Insect Repellent (3 hrs) 


\section{American Journal of Pharmaceutical Education 2017; 81 (10) Article 6100.}

questions: What disease(s) does this remedy affect; how is the herbal prepared for use; what is the active ingredient; is this active ingredient chemically related to any drugs in the formulary today; what is the mechanism of action of the herbal in each disease; are there herbal-drug interactions associated with this herbal; are there other toxicity concerns using this herbal (ie, concentration of toxins in other parts of the plant, dosage toxicity or preparations may concentrate toxins); are there commercial preparations of this herbal available and finally, has use of this herbal led to the development of official medications? A list of herbal remedies and the diseases they are purported to treat was given to the class as suggestions for topics. Although most students chose from this list, some students chose to write on the native medicinal plants of their home countries and were able to research these plants to create very informative and enlightening essays. The grading of the term papers followed a rubric (Appendix 2) and students who could submit well written, scholarly papers with in-depth descriptions of the mechanism of action of the herbal and expositive writing on the disease state itself were highly graded.

\section{RESULTS}

The students' overall grade in the course is based on their performance on three short-answer examinations ( $70 \%$ of the course grade), a term paper (10\%) and an oral presentation $(20 \%)$. This course has been offered 10 times in our curriculum. Student performance in the class has been outstanding (Table 2). The dip in performance in 2014 and 2015 reflect the class average on the term paper assignment; a significant portion of the students in these years wrote failing term papers. It is important to note that from 2008 to 2013, no term paper was assigned. In this time, there were limited elective offerings in our curriculum and the enrollment of this class surged to 40 students.

Table 2. Performance of Students Per Year on Individual Course Assessments

\begin{tabular}{ccccc}
\hline Year & Exams & Paper & Presentation & Final \\
\hline 2007 & 97 & 91 & 93 & 93 \\
2008 & 96 & 90 & 94 & 93 \\
2009 & 95 & a & 93 & 95 \\
2010 & 95 & a & 95 & 96 \\
2011 & 91 & a & 83 & 90 \\
2012 & 93 & a & 94 & 94 \\
2013 & 93 & a & 94 & 94 \\
2014 & 91 & 72 & 94 & 89 \\
2015 & 88 & 70 & 90 & 87 \\
2016 & 92 & 88 & 92 & 92 \\
\hline
\end{tabular}

${ }^{\mathrm{a}}$ No paper was assigned

Mean scores are presented as percentage of total points
It was felt that the grading of 25 or more term papers was too difficult to complete in a timely manner for one professor and that assessment was eliminated. However, faculty discussions in 2013 revealed a significant deficiency in our students' writing ability and the decision was made to re-implement the assignment as originally conceived.

Student evaluations for the 10 years have averaged 4.6 (Table 3), based on a 5-point Likert scale $(5=$ Strongly Agree). Although the class was held in the spring 2014, there was no course evaluation report generated. We have received several comments that the students who took this course tended to spend more time on the course materials because of their great interest in the subject. The evaluation comments also indicate that they feel more at ease assisting customers who ask advice on herbal remedies after taking this course. Others have indicated that they had previously thought herbal products to be "harmless" but have since recognized the potential toxicities of using herbal remedies without foreknowledge of their effects (Table 4).

\section{DISCUSSION}

Given the growing interest in alternative remedies and natural products, including a class on herbal medicines can only enhance the arsenal of tools our students need to counsel their patients effectively. ${ }^{3}$ Designing a course that addresses the particular herbal remedies used by patients in the school of pharmacy locale will be of great value to the students, especially when counseling their patients. The inclusion of commonly used herbal remedies that are commercially available, such as garlic, Gingko biloba, St. John's Wort, and ginger, is also essential as patients may be drawn to using these herbal remedies through the promotion of their uses and efficacies on popular health programs. ${ }^{17}$

Implementation of the course typically will require didactic presentations where the instructor presents novel

Table 3. Student Course Evaluation Scores (5=Excellent)

\begin{tabular}{lccc}
\hline Year & Score & Respondents & Enrollees \\
\hline 2007 & 4.8 & 20 & 20 \\
2008 & 4.7 & 15 & 20 \\
2009 & 4.7 & 22 & 31 \\
2010 & 4.9 & 25 & 26 \\
2011 & 3.5 & 7 & 28 \\
2012 & 4.7 & 25 & 30 \\
2013 & 4.9 & 11 & 39 \\
$2014^{\text {a }}$ & & & \\
2015 & 4.2 & 19 & 19 \\
2016 & 4.8 & 21 & 25 \\
\hline
\end{tabular}

${ }^{\mathrm{a}}$ No class evaluations were made during this period 


\section{American Journal of Pharmaceutical Education 2017; 81 (10) Article 6100.}

Table 4. Selected Student Comments as Part of the Course Evaluation

The open discussions in class are helpful in allowing the students to connect with the material as opposed to just memorizing it. Out of all the classes taken this semester, this single class is most applicable in regard to the myths and facts of home remedies and herbal therapy.

The information from this class leaked into a few other courses this semester. I am glad I chose this elective because it helped me with my other courses.

I feel like [this course] is really helpful in the practice of pharmacy, especially for me because I plan to practice in West Virginia. I actually had a patient come in to my pharmacy and ask a question about homeopathic remedies for gout. Someone had told him to use cherries. I was able to apply my knowledge of the class to my actual pharmacy practice

This class was amazing; I loved learning about how natural remedies and synthetic remedies can either work or hinder each other in treating a patient. The labs were fun and informational. The stories told by the professor only enhanced the fun I had in this class.

Great class overall, would recommend to others. Quite interesting. I thought the course was extremely informative and interesting. Considering that I grew up roaming the hills and being outdoors quite a bit, and having the ability to learn about some of the medicinal properties of the plants was very interesting.

material to the students. Lecture development typically took several hours per topic, with the total class requiring approximately two full weeks of preparation to finalize the material.

Discussion of concepts presented is essential for the implementation of this knowledge in patient counseling. Discussions also allow students within the classroom to recognize the diversity of perceptions regarding herbal medicine use. Keeping the class as informal as possible allows lively discourse that can sometimes drift away from the intended subject of the discussion, but this often creates a strong environment of enlightenment. One discussion, related to a supernatural cure involves using a potato to remove warts. The potato is cut and rubbed on the wart. It is then either buried or wrapped in red ribbon and placed such that another person might pick it up. The belief was that over time as the potato rots in the earth, the wart would disappear, or that the warts would be transferred to the person who picked up the ribbon. Several students who had grown up in Appalachia recognized the cure, while students from other cultures marveled that such an obscure "magical cure" was so well known.

There are significant regional differences across the United States, where folk beliefs and practices can influence the health care of our patients. For pharmacy schools in other regions, professors may want to analyze the alternative health practices in their area and adapt these topics into a course of folk medicine for their students. In the Southwest region of the country, there are strong influences from both Native American and Mexican American cultures that could be discussed. In the Northeast region of the country, many old folk remedies are employed as "tried and true" medicines that could have significant interactions with prescription medications. Future directions for our course involve expanding the material related to herb-drug interactions, developing case studies of pharmacodynamic and pharmacokinetic interactions. We recognize that offering this class as an elective allows us to delve more deeply into the belief systems of our region, but the time limit prevents us from expanding to these other regions of the country where some of our students are from.

\section{CONCLUSION}

An elective course on herbal remedies in the pharmacy curriculum was welcomed by both students and administration. The inclusion of coursework on herbal remedies enhances student understanding of over-the-counter products and will prepare them for patient questions regarding herbal remedies. As the use of complementary and alternative medicine strategies continues to be strong in our society, it is critical that educators of pharmacists include such course materials in their curriculum. By including the herbal practices of the specific region of the country in which the school of pharmacy resides, a professor may help the students better recognize potential issues that could impact the patients' health by better understanding the specific interactions of herbs used in that area and the medications their patients are taking.

\section{REFERENCES}

1. Wu CH, Wang CC, Tsai MT, Huang WT, Kennedy J. Trend and pattern of herb and supplement use in the United States: results from the 2002, 2007 and 2012 National Health Interview Surveys. Evid Based Complement Alternat Med. 2014;2014(872320):7.

2. Jiratchariyakul W, Mahady GB. Overivew of botanical status in EU, USA, and Thailand. Evid Based Complement Alternat Med. 2013;2013(480128): 13 .

3. Wheaton AG, Blanck HM, Gizlice Z, Reyes M. Medicinal herb use in a population-based survey of adults: prevalence and frequency of use, reasons for use, and use among their children. Ann Epidemiol. 2005;15(9):678-685. 


\section{American Journal of Pharmaceutical Education 2017; 81 (10) Article 6100.}

4. NIH State-of-the-Science Conference Statement on multivitamin/ mineral supplements and chronic disease prevention. NIH Consens State Sci Statements. 2006;23(2):1-30.

5. Rowell DM, Kroll DJ. Complementary and alternative medicine education in United States pharmacy schools. Am J Pharm Educ. 1998;62(4):412-419.

6. Shields KM, McQueen CE, Bryant PJ. Natural product education in schools of pharmacy in the United States. Am J Pharm Educ. 2003;67(1):Article 10.

7. Noureldin M, Murawski MM, Mason HL, Plake KS. Student pharmacists' attitudes toward complementary and alternative medicine. J Am Pharm Assoc. 2013;53(6):618-625.

8. Dwyer JT, Picciano MF, Betz JM, et al. Progress in developing analytical and label-based dietary supplement databases at the NIH Office of Dietary Supplements. J Food Compost Anal. 2008;21:S83-S93.

9. Coyne CA, Demian-Popescu C, Friend D. Social and cultural factors influencing health in southern West Virginia: a qualitative study. Preventing Chronic Disease. 2010 2006;3(4):Article 124. 10. Behringer B, Friedell GH. Appalachia: where place matters in health. Preventing Chronic Disease. 2006;3(4):Article 113.
11. Accreditation Council for Phamracy Education. Accreditation standards and guidelines for the professional program in pharmacy leading to the doctor of pharmacy degree. Chicago, IL; 2015.

12. Cavender A. A Folk Medical Lexicon of South Central Appalachia. Johnson City, TN: History of Medicine Society of Appalachia, James H. Quillen College of Medicine, East Tennessee State University; 1990.

13. Medina MS, Plaza CM, Stowe CD, et al. Center for the Advancement of Pharmacy Education 2013 educational outcomes. Am J Pharm Educ. 2013;77(8):Article 162.

14. Hatter I. Wildcrafting. http://www.wildcrafting.com/. Accessed June 14, 2011.

15. Riddle JM. Dioscorides on Pharmacy and Medicine. Austin, TX: University of Texas Press; 1985.

16. Ni M. The Yellow Emperor's Classic of Medicine: A New Translation of the Neijing Suwen with Commentary. Boston, MA: Shambhala Publications; 1995.

17. Bubela T, Koper M, Boon H, Caulfield T. Media portrayal of herbal remedies versus pharmaceutical clinical trials: impacts on decision. Med Law. June 2007 2007;26(2):363-373. 
American Journal of Pharmaceutical Education 2017; 81 (10) Article 6100.

Appendix 1. Student Oral Presentation Scoring Rubric ${ }^{\mathrm{a}}$

\begin{tabular}{|c|c|c|c|c|}
\hline$\overline{\text { Score }}$ & 4 & 3 & 2 & 1 \\
\hline \multicolumn{5}{|l|}{ Non-Verbal Skills } \\
\hline Eye Contact & $\begin{array}{l}\text { Holds attention of entire } \\
\text { audience with the use of } \\
\text { direct eye contact, } \\
\text { seldom looking at notes. }\end{array}$ & $\begin{array}{l}\text { Consistent use of direct eye } \\
\text { contact with audience, } \\
\text { but still returns to notes. }\end{array}$ & $\begin{array}{l}\text { Displayed minimal } \\
\text { eye contact with } \\
\text { audience, while } \\
\text { reading mostly } \\
\text { from the notes. }\end{array}$ & $\begin{array}{l}\text { No eye contact with } \\
\text { audience, as entire report } \\
\text { is read from notes. }\end{array}$ \\
\hline Body Language & $\begin{array}{l}\text { Movements seem fluid and } \\
\text { help the audience } \\
\text { visualize. }\end{array}$ & $\begin{array}{l}\text { Made movements or } \\
\text { gestures that enhance } \\
\text { articulation. }\end{array}$ & $\begin{array}{l}\text { Very little movement } \\
\text { or descriptive } \\
\text { gestures. }\end{array}$ & $\begin{array}{l}\text { No movement or } \\
\text { descriptive gestures. }\end{array}$ \\
\hline Poise & $\begin{array}{l}\text { Student is relaxed and self- } \\
\text { confident. }\end{array}$ & $\begin{array}{l}\text { Makes minor mistakes, but } \\
\text { quickly recovers. } \\
\text { Appears calm. }\end{array}$ & $\begin{array}{l}\text { Displays mild } \\
\text { tension; has trouble } \\
\text { recovering from } \\
\text { mistakes. }\end{array}$ & $\begin{array}{l}\text { Nervousness is obvious; } \\
\text { has trouble recovering } \\
\text { from mistakes. }\end{array}$ \\
\hline \multicolumn{5}{|l|}{ Verbal Skills } \\
\hline Enthusiasm & $\begin{array}{l}\text { Strong, positive attitude } \\
\text { during entire } \\
\text { presentation. }\end{array}$ & $\begin{array}{l}\text { Occasionally shows positive } \\
\text { attitude. }\end{array}$ & $\begin{array}{l}\text { Shows some } \\
\text { negativity toward } \\
\text { topic presented. }\end{array}$ & $\begin{array}{l}\text { Shows absolutely no } \\
\text { interest in topic } \\
\text { presented. }\end{array}$ \\
\hline Elocution & $\begin{array}{l}\text { Student uses a clear voice } \\
\text { and correct, precise } \\
\text { pronunciation of terms so } \\
\text { that all audience } \\
\text { members can hear } \\
\text { presentation. }\end{array}$ & $\begin{array}{l}\text { Student's voice is clear. } \\
\text { Student pronounces most } \\
\text { words correctly. Most } \\
\text { audience members can } \\
\text { hear presentation. }\end{array}$ & $\begin{array}{l}\text { Student's voice is } \\
\text { low. Student } \\
\text { incorrectly } \\
\text { pronounces terms. }\end{array}$ & $\begin{array}{l}\text { Audience members have } \\
\text { difficulty hearing } \\
\text { presentation. }\end{array}$ \\
\hline \multicolumn{5}{|l|}{ Content } \\
\hline $\begin{array}{l}\text { Subject } \\
\text { Knowledge }\end{array}$ & $\begin{array}{l}\text { Student demonstrates } \\
\text { knowledge by answering } \\
\text { all class questions with } \\
\text { explanations and } \\
\text { elaboration. }\end{array}$ & $\begin{array}{l}\text { Student is at ease with } \\
\text { expected answers to all } \\
\text { questions, without } \\
\text { elaboration. }\end{array}$ & $\begin{array}{l}\text { Student is } \\
\text { uncomfortable with } \\
\text { information and is } \\
\text { able to answer only } \\
\text { rudimentary } \\
\text { questions. }\end{array}$ & $\begin{array}{l}\text { Student does not have } \\
\text { grasp of information; } \\
\text { student cannot answer } \\
\text { questions about subject. }\end{array}$ \\
\hline Organization & $\begin{array}{l}\text { Student presents } \\
\text { information in logical, } \\
\text { interesting sequence. } \\
\text { Introduction, } \\
\text { Development of Material } \\
\text { and Conclusion included. }\end{array}$ & $\begin{array}{l}\text { Student presents } \\
\text { information in logical } \\
\text { sequence which audience } \\
\text { can follow. Introduction, } \\
\text { Development of Material } \\
\text { and Conclusion included. }\end{array}$ & $\begin{array}{l}\text { Audience has } \\
\text { difficulty following } \\
\text { presentation. } \\
\text { Introduction, } \\
\text { Development or } \\
\text { Conclusion is } \\
\text { missing. }\end{array}$ & $\begin{array}{l}\text { Audience cannot } \\
\text { understand presentation } \\
\text { because there is no } \\
\text { sequence of information. }\end{array}$ \\
\hline Mechanics & $\begin{array}{l}\text { Presentation has no } \\
\text { misspellings or } \\
\text { grammatical errors. }\end{array}$ & $\begin{array}{l}\text { Presentation has no more } \\
\text { than two misspellings or } \\
\text { grammatical errors. }\end{array}$ & $\begin{array}{l}\text { Presentation has three } \\
\text { misspellings and/or } \\
\text { grammatical errors. }\end{array}$ & $\begin{array}{l}\text { Presentation has four or } \\
\text { more spelling and/or } \\
\text { grammatical errors. }\end{array}$ \\
\hline \multicolumn{5}{|c|}{ PowerPoint Presentation } \\
\hline Text & $\begin{array}{l}\text { All slides present one idea } \\
\text { and a few supporting } \\
\text { facts. }\end{array}$ & $\begin{array}{l}\text { Most slides present one idea } \\
\text { and a few supporting } \\
\text { facts. }\end{array}$ & $\begin{array}{l}\text { Most slides present } \\
\text { one idea but too } \\
\text { many words. }\end{array}$ & $\begin{array}{l}\text { Most slides present } \\
\text { multiple ideas and/or too } \\
\text { many words. }\end{array}$ \\
\hline
\end{tabular}


American Journal of Pharmaceutical Education 2017; 81 (10) Article 6100.

Appendix 1. (Continued)

\begin{tabular}{|c|c|c|c|c|}
\hline Score & 4 & 3 & 2 & 1 \\
\hline Font & $\begin{array}{l}\text { Font on all slides is large } \\
\text { enough to be read at } \\
\text { a distance. }\end{array}$ & $\begin{array}{l}\text { Font on most slides is large } \\
\text { enough to be read at } \\
\text { a distance. }\end{array}$ & $\begin{array}{l}\text { Fond on most slides is } \\
\text { too small to be read } \\
\text { at a distance. }\end{array}$ & $\begin{array}{l}\text { Font on all slides is too } \\
\text { small to be read at } \\
\text { a distance. }\end{array}$ \\
\hline Contrast & $\begin{array}{l}\text { There is good contrast } \\
\text { between the font and } \\
\text { background on all slides. }\end{array}$ & $\begin{array}{l}\text { There is good contrast } \\
\text { between the font and } \\
\text { background on most } \\
\text { slides. }\end{array}$ & $\begin{array}{l}\text { The lack of contrast } \\
\text { between the font } \\
\text { and background } \\
\text { makes the text } \\
\text { difficult to read. }\end{array}$ & $\begin{array}{l}\text { The lack of contrast } \\
\text { between the font and the } \\
\text { background makes the } \\
\text { text impossible to read. }\end{array}$ \\
\hline $\begin{array}{l}\text { Images and } \\
\text { Layout }\end{array}$ & $\begin{array}{l}\text { All slides contain one } \\
\text { powerful, high-quality } \\
\text { image per slide which } \\
\text { helps the audience } \\
\text { understand the content. } \\
\text { Layout is visually } \\
\text { pleasing. }\end{array}$ & $\begin{array}{l}\text { Most slides include one } \\
\text { powerful, high-quality } \\
\text { image per slide which } \\
\text { enhances the content. } \\
\text { Layout uses most space } \\
\text { appropriately. }\end{array}$ & $\begin{array}{l}\text { Most images are clip } \\
\text { art or images are } \\
\text { too large/small or } \\
\text { poor quality. } \\
\text { Layout shows some } \\
\text { structure. }\end{array}$ & $\begin{array}{l}\text { Images are distracting } \\
\text { decorations that create } \\
\text { a busy feeling and } \\
\text { detract from the content. } \\
\text { Layout is cluttered and } \\
\text { confusing. }\end{array}$ \\
\hline $\begin{array}{l}\text { Presentation } \\
\text { Style }\end{array}$ & $\begin{array}{l}\text { Student uses text on slides } \\
\text { as prompts for original } \\
\text { narration. }\end{array}$ & $\begin{array}{l}\text { Student reads text on slides } \\
\text { and elaborates } \\
\text { comfortably. }\end{array}$ & $\begin{array}{l}\text { Student reads text on } \\
\text { slides, adding few } \\
\text { comments. }\end{array}$ & $\begin{array}{l}\text { Student just reads text on } \\
\text { slides. }\end{array}$ \\
\hline
\end{tabular}

"Adapted from NCTE/IRA "Read Write Think" www.readwritethink.org 


\section{American Journal of Pharmaceutical Education 2017; 81 (10) Article 6100.}

Appendix 2. Term Paper Scoring Rubric ${ }^{\mathrm{a}}$

\begin{tabular}{|c|c|c|c|c|}
\hline$\overline{\text { Score }}$ & 4 & 3 & 2 & 1 \\
\hline Focus \& Details & $\begin{array}{l}\text { There is one clear, } \\
\text { well-focused topic. } \\
\text { Main ideas are clear and } \\
\text { are well supported by } \\
\text { detailed and accurate } \\
\text { information. }\end{array}$ & $\begin{array}{l}\text { There is one clear, } \\
\text { well-focused topic. } \\
\text { Main ideas are clear but } \\
\text { are not well supported } \\
\text { by detailed information. }\end{array}$ & $\begin{array}{l}\text { There is one topic. Main } \\
\text { ideas are somewhat } \\
\text { clear. }\end{array}$ & $\begin{array}{l}\text { The topic and main ideas } \\
\text { are not clear. }\end{array}$ \\
\hline Organization & $\begin{array}{l}\text { The introduction is } \\
\text { inviting, states the main } \\
\text { topic, and provides an } \\
\text { overview of the paper. } \\
\text { Information is relevant } \\
\text { and presented in } \\
\text { a logical order. The } \\
\text { conclusion is strong. }\end{array}$ & $\begin{array}{l}\text { The introduction states the } \\
\text { main topic and provides } \\
\text { an overview of the } \\
\text { paper. A conclusion is } \\
\text { included. }\end{array}$ & $\begin{array}{l}\text { The introduction states the } \\
\text { main topic. A } \\
\text { conclusion is included. }\end{array}$ & $\begin{array}{l}\text { There is no clear } \\
\text { introduction, structure, } \\
\text { or conclusion. }\end{array}$ \\
\hline Voice & $\begin{array}{l}\text { The author's purpose of } \\
\text { writing is very clear and } \\
\text { there is strong evidence } \\
\text { of attention to audience. } \\
\text { The author's extensive } \\
\text { knowledge and/or } \\
\text { experience with the } \\
\text { topic is/are evident. }\end{array}$ & $\begin{array}{l}\text { The author's purpose of } \\
\text { writing is somewhat } \\
\text { clear, and there is some } \\
\text { evidence of attention to } \\
\text { audience. The author's } \\
\text { knowledge and/or } \\
\text { experience with the } \\
\text { topic is/are evident. }\end{array}$ & $\begin{array}{l}\text { The author's purpose of } \\
\text { writing is somewhat } \\
\text { clear, and there is } \\
\text { evidence of attention to } \\
\text { audience. The author's } \\
\text { knowledge and/or } \\
\text { experience with the } \\
\text { topic is/are limited. }\end{array}$ & $\begin{array}{l}\text { The author's purpose of } \\
\text { writing is unclear. }\end{array}$ \\
\hline Word Choice & $\begin{array}{l}\text { The author uses vivid } \\
\text { words and phrases. The } \\
\text { choice and placement of } \\
\text { words seems accurate, } \\
\text { natural, and not forced. }\end{array}$ & $\begin{array}{l}\text { The author uses vivid } \\
\text { words and phrases. The } \\
\text { choice and placement of } \\
\text { words is inaccurate at } \\
\text { times and/or seems } \\
\text { overdone. }\end{array}$ & $\begin{array}{l}\text { The author uses words that } \\
\text { communicate clearly, } \\
\text { but the writing lacks } \\
\text { variety. }\end{array}$ & $\begin{array}{l}\text { The writer uses a limited } \\
\text { vocabulary. Jargon or } \\
\text { clichés may be present } \\
\text { and detract from the } \\
\text { meaning. }\end{array}$ \\
\hline $\begin{array}{l}\text { Sentence } \\
\text { Structure, } \\
\text { Grammar, } \\
\text { Mechanics \& } \\
\text { Spelling }\end{array}$ & $\begin{array}{l}\text { All sentences are well } \\
\text { constructed and have } \\
\text { varied structure and } \\
\text { length. The author } \\
\text { makes no errors in } \\
\text { grammar, mechanics, } \\
\text { and/or spelling. }\end{array}$ & $\begin{array}{l}\text { Most sentences are well } \\
\text { constructed and have } \\
\text { varied structure and } \\
\text { length. The author } \\
\text { makes a few errors in } \\
\text { grammar, mechanics, } \\
\text { and/or spelling, but they } \\
\text { do not interfere with } \\
\text { understanding. }\end{array}$ & $\begin{array}{l}\text { Most sentences are well } \\
\text { constructed, but they } \\
\text { have a similar structure } \\
\text { and/or length. The } \\
\text { author makes several } \\
\text { errors in grammar, } \\
\text { mechanics, and/or } \\
\text { spelling that interfere } \\
\text { with understanding. }\end{array}$ & $\begin{array}{l}\text { Sentences sound } \\
\text { awkward, are } \\
\text { distractingly repetitive, } \\
\text { or are difficult to } \\
\text { understand. The author } \\
\text { makes numerous errors } \\
\text { in grammar, } \\
\text { mechanics, and/or } \\
\text { spelling that interfere } \\
\text { with understanding. }\end{array}$ \\
\hline
\end{tabular}

adapted from ReadWriteThink, copyright 2013 International Reading Association/National Council of Teachers of English 